\title{
CORRESPONDENCE
}

\section{Lake District copper}

SIR - I have read Mr Dagger's paper (Geol. Mag. 114 (3), 1977) with interest. I can hardly disagree with his conclusions since similar opinions are about to be published in the forthcoming Y.G.S. volume on the Geology of the Lake District (Firman, in the press). Copper mines and mineralization are more widespread than Mr Dagger's map (fig. 4) implies. In the Duddon Valley-Eskdale region copper mines at Logan Beck (174916) and on Hesk Fell (178942) are shown on six-inch Ordnance Survey maps, but are not otherwise documented. Near Ulpha (185924) similar quartz-pyrite-chalcopyrite veins in the Borrowdale volcanics were explored. Trials for copper were also made in the southern, xenolithic part of the Eskdale Granite (135908). All workings were in E-W trending veins and are situated over the southern wall of the Lake District batholith. No production statistics are available but, judging from the spoil heaps, the mines in the DuddonEskdale area appear to have been more extensive than some, such as Burnbanks, which are shown on $\mathrm{Mr}$ Dagger's map.

Although it is true that economic copper deposits are restricted to the Skiddaw Slates and Borrowdale volcanics it should be noted the Cruzat \& Meyer (Trans. Inst. Min. Metall., 1974, pp. B 131-4) have, on the basis of a statistical study of stream sediment data, predicted that economic concentrations of copper, should occur in the SW Lake District in areas in which Silurian strata predominate. Work in hand has so far failed to confirm this prediction. Copper minerals also occur, sometimes in economic concentrations, in NW trending haematite veins in the Carboniferous (e.g. Anty Cross, near Dalton-in-Furness and Papcastle near Cockermouth) and in the Eskdale Granite aureole especially in Spothow Gill (204006). Thus a later period of copper mineralization also occurs around the periphery of the batholith, suggesting that post-Carboniferous copper mineralization may also occur elsewhere in the Lake District. Almost all base metal and haematite mineralization in the Lower Palaeozoic rocks of the Lake District is situated over the batholith and it appears that this not only provided a heat source when the component intrusions were initially emplaced but later, during periods of isostatic uplift, provided conduits for recirculating mineralizing brines (Firman, in the press).

Department of Geology

R. J. FIRMAN

University Park

Nottingham

Ist August, 1977

SIR - I was encouraged by Dr Firman's agreement with the conclusions of my paper on copper mineralization at Coniston (Geol. Mag. 114 (3), 1977), and am most grateful to him for pointing out additional occurrences of quartz-pyrite-chalcopyrite type in the Lake District. However, his comments about copper minerals associated with haematite veins, although of interest, are less relevant to the subject of the paper, and the use of the term 'copper mineralization' to describe these occurrences conveys the wrong impression - they represent one or more phases of haematite mineralization which has in places remobilized small amounts of copper from pre-existing veins, or from some other source.

Although I would agree with the assertion that the later mineralization in the Lake District was controlled to some extent by isostatic uplift of the batholith, the relationship is less clear for the haematite veins than for the lead-zinc deposits. In particular, the whole of the haematite mineralization of south Furness, although occurring in Carboniferous rocks on a basement of Lower Palaeozoics, is located between 10 and $20 \mathrm{~km}$ from the batholith. It seems difficult to explain this distribution solely on the basis of uplift of the granites.

Earth Sciences Section

G. W. DAGGER

Department of Physics

North Staffordshire Polytechnic

Stoke-on-Trent

8th August, 1977 